\title{
Effect of Temperature on the Properties and Microstructures of Carbon Refractories for Blast Furnace
}

\begin{abstract}
XILAI CHEN, YAWEI LI, YUANBING LI, SHENGLI JIN, LEI ZHAO, and SHAN GE
The effects of temperature on phase composition, microstructure, and properties of silicon-containing blast furnace (BF) carbon refractories after firing in coke breeze packing at $1000{ }^{\circ} \mathrm{C}$ to $1600^{\circ} \mathrm{C}$ were studied with the aid of X-ray diffraction (XRD), scanning electron microscopy (SEM), energy-dispersive X-ray, mercury porosimetry, and a laser thermal conductivity meter. The results showed that silicon played a dominant role in the evolution of phase, microstructure, and properties. The amount of $\mathrm{SiC}$ whiskers increased with temperature. The phase in the outer part of the specimen was cristobalite balls, and its content decreased and $\beta$-SiC whisker increased in the inner part of the specimen. The phase and microstructure development with firing temperature influenced the properties. The bulk density, strength, and $<1-\mu \mathrm{m}$ micropore volume of open pores were highest, whereas the apparent and total porosity, mean pore size, and thermal conductivity were lowest for specimens fired at $1400{ }^{\circ} \mathrm{C}$. Moreover, the thermal conductivity was affected by pore structure and phases formed after firing.
\end{abstract}

DOI: $10.1007 / \mathrm{s} 11661-009-9850-0$

(C) The Author(s) 2009. This article is published with open access at Springerlink.com

\section{INTRODUCTION}

THE blast furnace (BF) is used at the beginning of the iron production process to reduce the iron oxide ores. Owing to the need to increase productivity in recent years, it has become necessary to enlarge the volume of the $\mathrm{BF}$ and increase the hot metal temperature. In the lower portion of the BF, where the molten iron accumulates, especially in the portion below the iron notch, the surface of the lining refractory layer is in contact with the molten metal at a temperature of $1400{ }^{\circ} \mathrm{C}$ to $1600{ }^{\circ} \mathrm{C}$. Thereafter, the lining refractory layer is often eroded and damaged by various factors, such as the molten metal penetration, thermal stresses, carbon dissolution, carbon oxidation, alkalia attack, etc. ${ }^{[-6]}$ Thus, it has been of established consensus that the lifetime of a BF is mainly determined by the rate of erosion and corrosion of the hearth refractory lining.

In order to prevent damage to the $\mathrm{BF}$ carbon refractories, it is required that the pore be made small enough to reduce the penetration of molten metal and reactive gases and the thermal conductivity high enough to reduce thermal stresses. Thus, super-micropore and high thermal conductivity are pursued by manufacturers and producers. However, the relationship between micropore size and thermal conductivity has not been adequately established. Silicon is commonly added in the production of carbon bricks, and its reaction mechanism and role in enlarging performance are

XILAI CHEN, Postdoctoral Student, YAWEI LI, YUANBING LI, and LEI ZHAO, Professors, SHENGLI JIN, Teacher, and SHAN GE, Senior Engineer, are with the The Hubei Province Key Laboratory of Ceramics and Refractories, Wuhan University of Science \& Technology, Wuhan 430081, P.R. China. Contact e-mail: chengxilai@sina.com

Manuscript submitted August 21, 2008

Article published online June 6, 2009 reported. ${ }^{[7-11]}$ It has been suggested that the temperature plays an important role in the evolution of siliconcontaining compounds during heat treatment under reducing atmosphere. ${ }^{[12-15]}$ However, few reports can be found in the literature regarding the effect of temperature of the heat-treatment process on performance and microstructures developed for $\mathrm{BF}$ carbon refractories.

In the present work, the evolution of phases, microstructures, and performance of $\mathrm{BF}$ carbon refractories during heat treatment were investigated in a $\mathrm{CO}-\mathrm{N}_{2}$ atmosphere, which aims to establish a theoretical basis for the development and production of super-highquality carbon refractories for the BF.

\section{EXPERIMENTAL}

\section{A. Raw Materials and Refractories Fabrication}

Electric-calcined anthracite granules and fine powder, graphite, corundum, metallic silicon, and silicon carbide were used as the raw materials, and a mixture of coal-tar pitch (softening point: $80{ }^{\circ} \mathrm{C}$ to $90{ }^{\circ} \mathrm{C}$ ) and toluene insoluble ( $\leq 25 \mathrm{wt} \mathrm{pct}$ ) was used as a binder. The chemical compositions of all the raw materials, which were all from China, are shown in Table I. The batch containing $50 \mathrm{wt}$ pct electric-calcined anthracite, $16.5 \mathrm{wt}$ pct graphite, $6 \mathrm{wt}$ pct corundum, $8 \mathrm{wt}$ pet silicon, $0.5 \mathrm{wt}$ pct silicon carbide, and binder (19 wt pct) were kneaded and pressed following the standard commercial practice. Cubes $(-50 \times 50 \times 50 \mathrm{~mm})$ were cut from the prepared carbon bricks, embedded in carbon powder in an alumina crucible with a lid, and heated in the temperature range of $1000{ }^{\circ} \mathrm{C}$ to $1600^{\circ} \mathrm{C}$ in an electric furnace with air atmosphere outside the crucible. The furnace was heated from room temperature to $1000{ }^{\circ} \mathrm{C}$ at $5{ }^{\circ} \mathrm{C} / \mathrm{min}$ and then from $1000{ }^{\circ} \mathrm{C}$ to 
Table I. Chemical Compositions of the Raw Materials (Weight Percent)

\begin{tabular}{|c|c|c|c|c|c|c|c|c|c|}
\hline & $\mathrm{C}$ & $\mathrm{Al}_{2} \mathrm{O}_{3}$ & $\mathrm{SiO}_{2}$ & $\mathrm{Si}$ & $\mathrm{SiC}$ & Ash & Volatile & $\mathrm{Na}_{2} \mathrm{O}$ & $\mathrm{Fe}$ \\
\hline Electric-calcined Anthracite & 93.12 & 3.87 & 3.96 & & & 7.34 & 1.35 & & \\
\hline Graphite & $\geq 97$ & & & & & 1.4 & & & \\
\hline Corundum & & $\geq 98$ & & & & & & $\leq 0.8$ & \\
\hline Metallic silicon & & & & $\geq 98$ & & & & & 0.5 \\
\hline Silicon carbide & & & & & $\geq 95$ & & & & 0.5 \\
\hline Coal-tar pitch & & & & & & $\leq 0.5$ & 55 to 75 & & \\
\hline
\end{tabular}

$1200{ }^{\circ} \mathrm{C}$ at $4{ }^{\circ} \mathrm{C} / \mathrm{min}$ and finally from $1200{ }^{\circ} \mathrm{C}$ to $1600{ }^{\circ} \mathrm{C}$ at $3{ }^{\circ} \mathrm{C} / \mathrm{min}$. The soaking time at the final temperature was 3 hours.

\section{B. Tests and Characterization Methods}

The properties of the fired specimens were characterized by measurements of weight changes, bulk density, apparent porosity, true density, and cold crushing strength (CCS); the closed porosity and total porosity were then obtained. The amount of unreacted silicon in the specimens was measured semiquantitatively by X-ray diffraction (XRD). Micropore size distribution was examined from samples of $\sim 6 \times 6 \times 6 \mathrm{~mm}$ by mercury porosimetry (Autopore IV9500, Micromeritics Instrument Corp., Norcross, GA). Thermal conductivity was measured by a laser thermal conductivity meter (Flashline 5000, Anter Corp., Pittsburgh, PA) from the samples of $\sim$ i.d. $12.5 \times 2.5 \mathrm{~mm}$; five specimens were used, and the average value of thermal conductivity was obtained. The thermal conductivity was measured in a direction parallel to the forming direction of the initial carbon refractories. The phase composition and microstructure of the specimens were analyzed and observed by XRD (PHILIPS, * X'Pert Pro, using Ni-filtered, $\mathrm{Cu}$

*PHILIPS is a trademark of Philips Electronic Instruments Corp., Mahwah, NJ.

$K_{\alpha}$ radiation at a scanning speed of $2 \mathrm{deg} / \mathrm{min}$ of $16{ }^{\circ} \mathrm{C}$ ), scanning electron microscopy (SEM, PHILIPS, XL30 TMP), and energy-dispersive-X-ray spectroscopy (EDS, EDAX, Phoenix, The Netherlands).

\section{RESULTS AND DISCUSSION}

\section{A. Phase Evolution}

The XRD patterns of the specimens fired at different temperatures are shown in Figure 1. $\beta$-SiC and $\mathrm{SiO}_{2}$ phases are detected together with corundum, graphite, and silicon phases in the specimens fired at $1200{ }^{\circ} \mathrm{C}$. With an increase in the firing temperature, the $\mathrm{X}$-ray peak intensity associated with $\mathrm{SiO}_{2}$ decreased and then disappeared completely after firing at $1400{ }^{\circ} \mathrm{C}$, while the peak intensity associated with $\mathrm{SiC}$ increased gradually. The $\mathrm{Si}$ peak intensity decreased a little with the formation of $\mathrm{SiC}$ phase, as shown in the X-ray patterns. At $1300{ }^{\circ} \mathrm{C}$, no residual $\mathrm{Si}$ could be detected in the

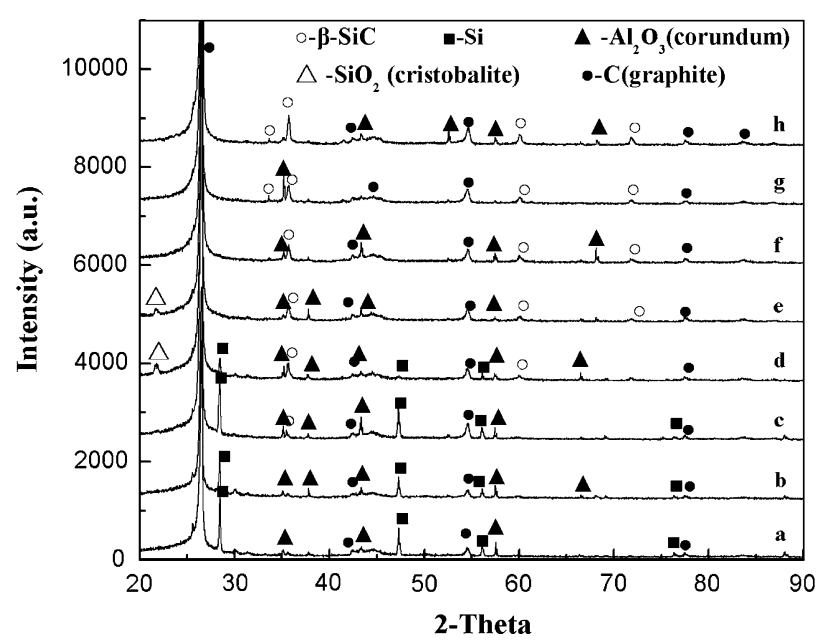

Fig. 1-XRD patterns of specimens fired at indicated temperatures in a coke bed: (a) room temperature, (b) $1000{ }^{\circ} \mathrm{C},(c) 1100{ }^{\circ} \mathrm{C},(d)$ $1200{ }^{\circ} \mathrm{C},(e) 1300{ }^{\circ} \mathrm{C},(f) 1400{ }^{\circ} \mathrm{C},(g) 1500{ }^{\circ} \mathrm{C}$, and $(h) 1600{ }^{\circ} \mathrm{C}$.

specimens. Surprisingly, no other phases could be detected, such as the $\mathrm{Si}_{3} \mathrm{~N}_{4}, \mathrm{Si}-\mathrm{O}-\mathrm{N}$, or $\mathrm{Si}-\mathrm{Al}-\mathrm{O}-\mathrm{N}$ compounds, which usually form in the fired Si-containing carbon materials. ${ }^{[16]}$

\section{B. Microstructures}

\section{Unburned microstructure}

The typical matrix SEM micrograph of the unburned specimen is illustrated in Figure 2. The matrix was mainly composed of graphite (dark contrast), corundum ( $\sim 50 \mu \mathrm{m}$, light gray contrast), electric-calcined anthracite (light dark contrast), fine $\mathrm{Si}$ (white contrast), fine $\mathrm{SiC}$ (gray contrast), and a trace of Fe-containing silicate impurities (bright contrast). The impurities were from the electric-calcined anthracite and graphite raw materials.

\section{Microstructures of burned specimens}

A polished section of a specimen fired at $1200{ }^{\circ} \mathrm{C}$ is presented in Figure 3(a). Unreacted $\mathrm{Si}$ still remained in the matrix, although product phases such as $\mathrm{SiC}$ and $\mathrm{SiO}_{2}$ began to form on the surface of $\mathrm{Si}$, and a large hole was present in the Si particle. At $1400{ }^{\circ} \mathrm{C}$ (Figure 3(b)), only a little unreacted $\mathrm{Si}$ remained, which could not be detected by XRD, but more $\mathrm{SiC}$ whiskers formed around the Si particle or in the holes, which were the original sites occupied by $\mathrm{Si}$ particles. No $\mathrm{Si}$ was 
detected in specimens fired at $1600{ }^{\circ} \mathrm{C}$ (Figure 3(c)), but the $\mathrm{SiC}$ whiskers and more $\mathrm{SiC}$ particles with different sizes formed in the holes and matrix.

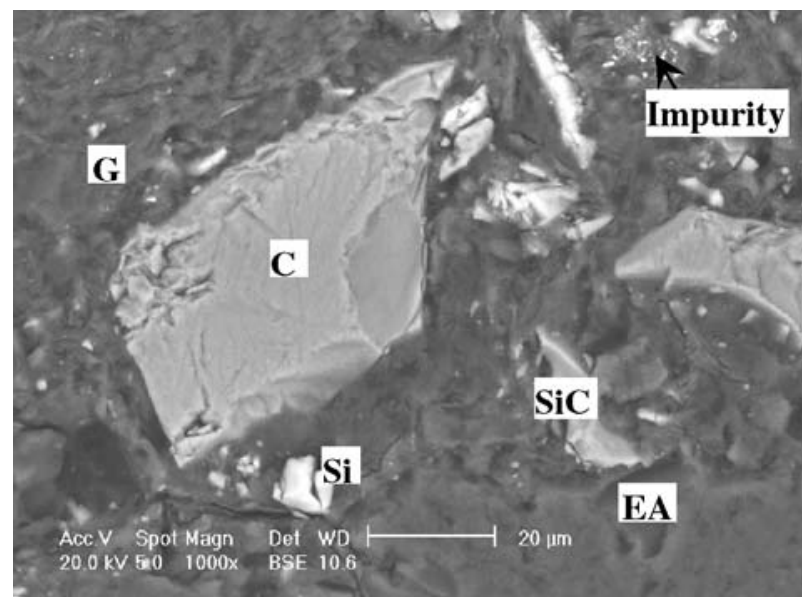

Fig. 2-Matrix SEM micrograph of specimen unburned (magnification 1000 times): G, graphite; C, corundum; and EA, electriccalcined anthracite.
The fracture surface of samples fired at different temperatures was studied by SEM. A large number of ball-like substances could be easily identified in the matrix of the samples fired at $1100{ }^{\circ} \mathrm{C}$. Only $\mathrm{Si}$ and $\mathrm{O}$ elements were detected by EDS in these substances; and, based on the XRD results, it may be concluded that these ball substances were cristobalite (Figure 4(a)). At $1200{ }^{\circ} \mathrm{C}$, the amount of cristobalite tended to decrease and whiskers of nanosize in diameter and micrometer size in length appeared (Figure 4(b)). According to XRD and EDS analyses, such whiskers were $\beta$-SiC, which was the same as that reported in previous studies. ${ }^{[12]} \mathrm{A}$ few of the dumbbell-shaped whiskers were also found in the interior part of the matrix at $1200{ }^{\circ} \mathrm{C}$ along with some cristobalite balls and straight $\beta$-SiC whiskers. The ball-like cristobalite was most difficult to identify in samples above $1200{ }^{\circ} \mathrm{C}$. Temperature played an important role in the growth and increase of $\beta$-SiC whiskers. At $1400{ }^{\circ} \mathrm{C}$, the $\beta$-SiC whiskers were dendritic, interlocked with each other to form intertextures, and were uniformly distributed in the matrix (Figure 4(c)). Up to $1600{ }^{\circ} \mathrm{C}$ (Figure $4(\mathrm{~d})$ ), the $\beta$-SiC whiskers were straighter and their ratio of length to diameter increased significantly, whereas some of them curled and less

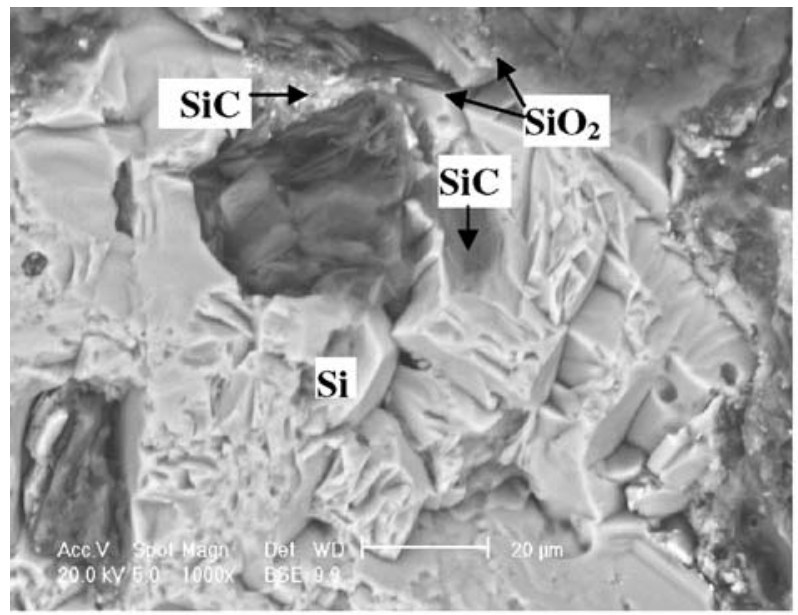

(a) $1200^{\circ} \mathrm{C}$

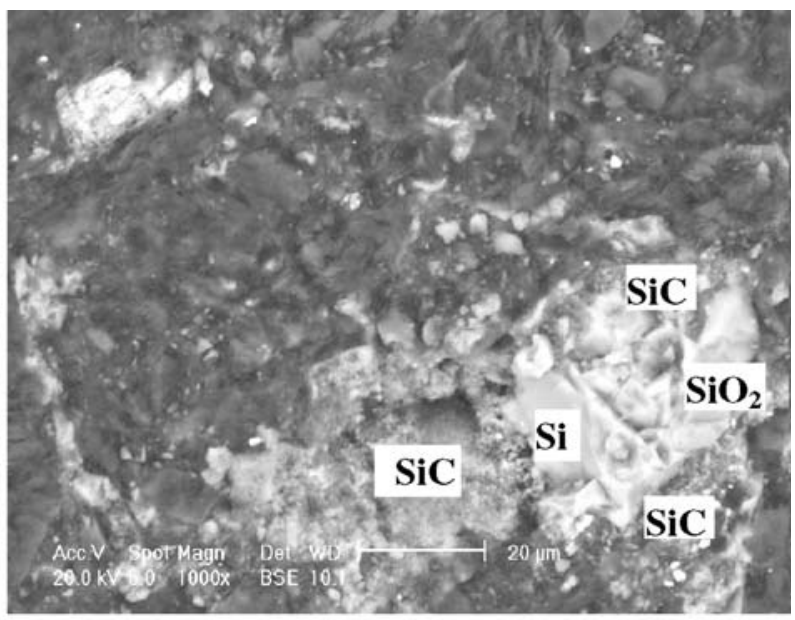

(b) $1400^{\circ} \mathrm{C}$

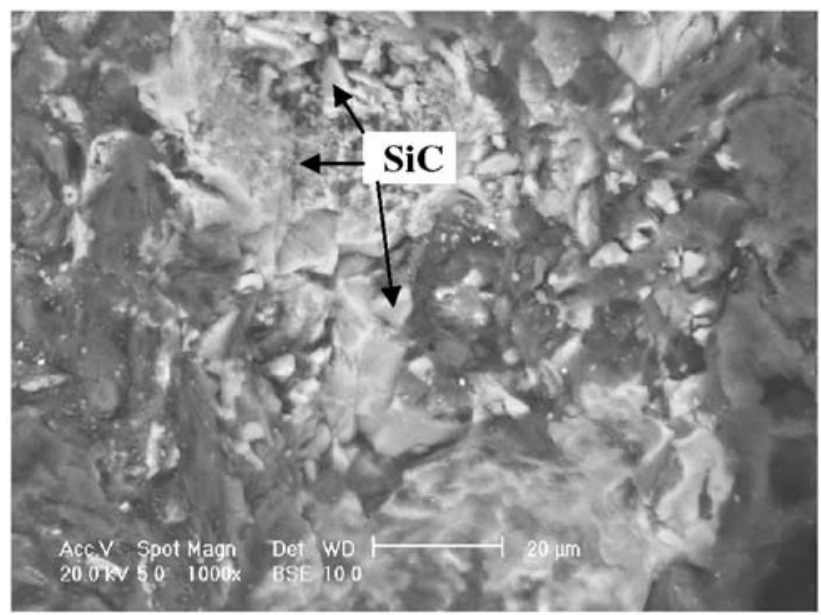

(c) $1600^{\circ} \mathrm{C}$

Fig. 3-SEM micrographs of silicon evolution of specimens fired at indicated temperatures (magnification 1000 times). 


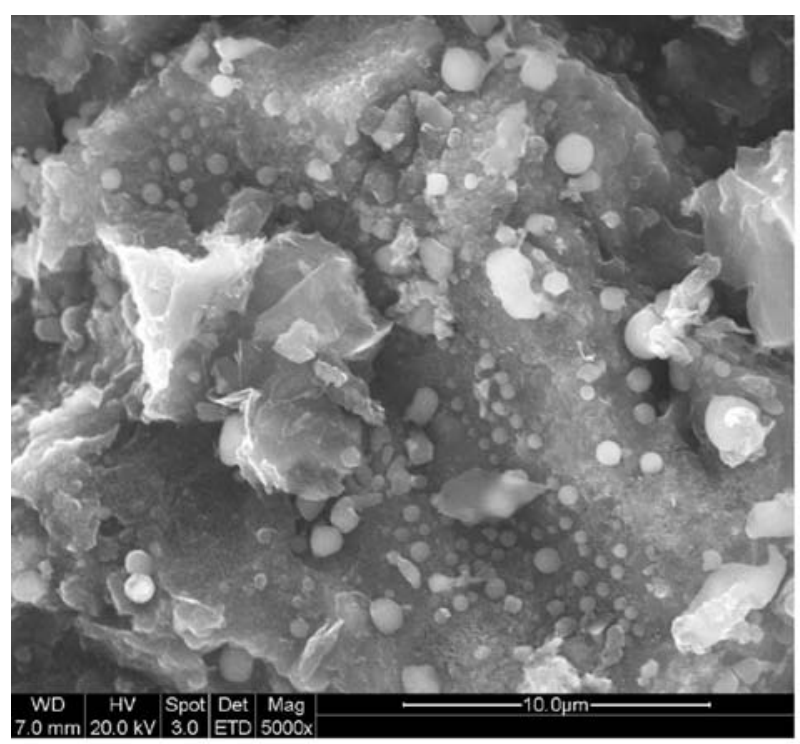

(a) $1100^{\circ} \mathrm{C}$

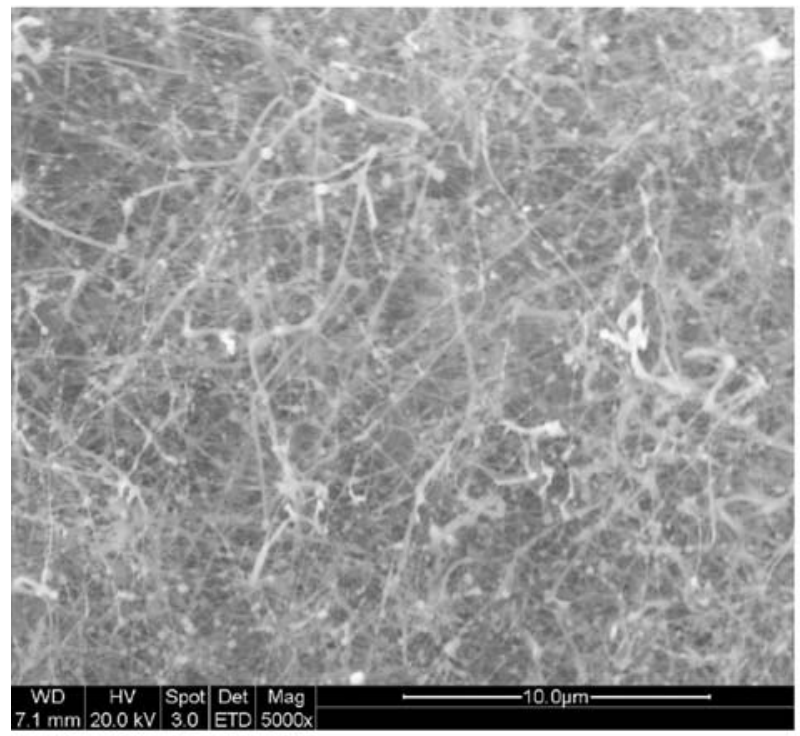

(c) $1400^{\circ} \mathrm{C}$

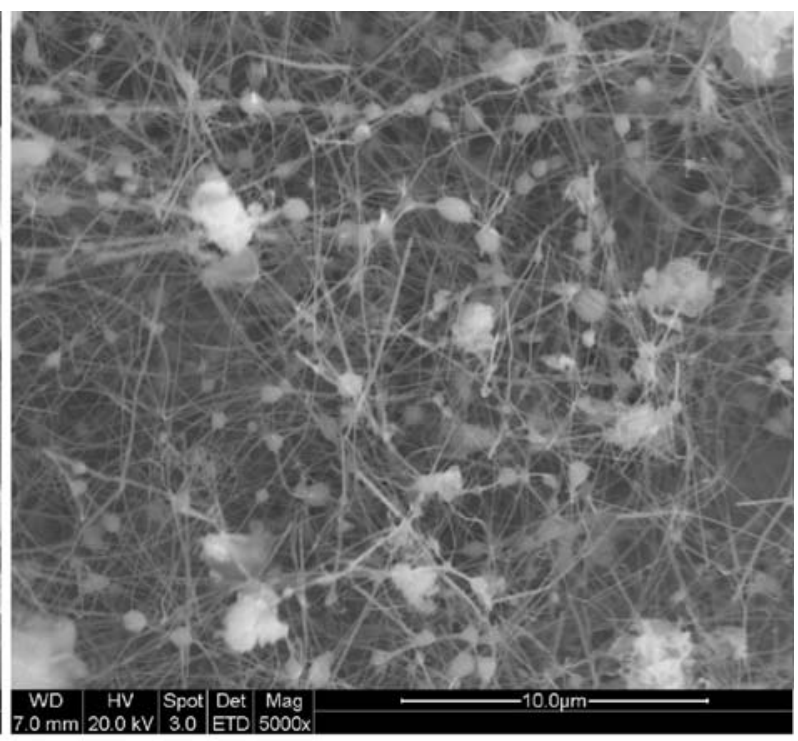

(b) $1200^{\circ} \mathrm{C}$

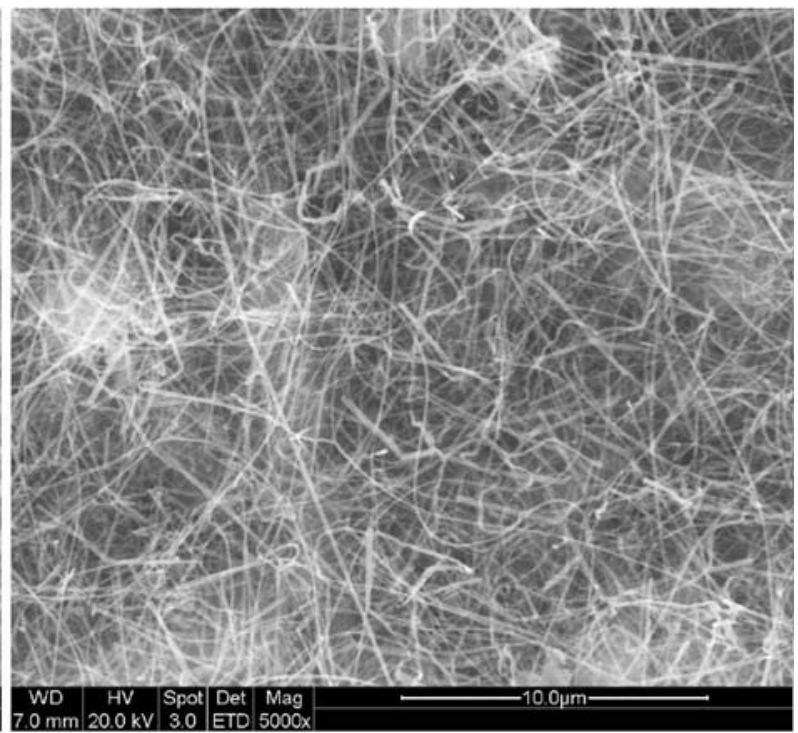

(d) $1600^{\circ} \mathrm{C}$

Fig. 4-Fracture surface SEM morphologies of specimens fired at indicated temperatures (magnification 5000 times).

uniformly distributed in the matrix. Similar microstructure evolution with temperature was also observed in $\mathrm{Al}_{2} \mathrm{O}_{3}-\mathrm{ZrO}_{2}-\mathrm{C}$ composite refractories; ${ }^{[12]}$ however, the onset temperature of phase evolution observed in this work was $\sim 100{ }^{\circ} \mathrm{C}$ lower than that observed in previous investigations.

The evolution of phases in the fired samples not only depended on the temperature, but also took place in different locations of the same sample. The color of fracture surface of the burned samples started to change from $1200{ }^{\circ} \mathrm{C}$. The gray-white color of the fringe layer, which was about $5 \mathrm{~mm}$ in thickness, changed to graygreen color at the interior at $1200{ }^{\circ} \mathrm{C}$, and the same phenomenon was found at higher temperatures. The thickness of the fringe layer decreased to $\sim 2 \mathrm{~mm}$ at $1300{ }^{\circ} \mathrm{C}$ and then remained constant with further increase in temperature. Figure 5 indicates the phase change from the outer to interior part of the sample fired at $1400{ }^{\circ} \mathrm{C}$. Many balls with several micrometers in diameter were observed in the fringe layer, which were identified as cristobalite by a combination of energydispersive X-ray and XRD analysis (Figure 5(a)). The volume of balls reduced and the amount of $\beta$-SiC whiskers increased in the middle layer (Figure 5(b)). In the interior of the sample, the balls disappeared and only $\beta$-SiC whiskers were present (Figure 5(c)).

\section{Thermodynamics analysis}

The thermodynamic analysis was undertaken to relate those phases formed in the fired specimens to the ones predicted at equilibrium. The amount of $\mathrm{SiC}$ added in the batch was small and thus was not considered in the 


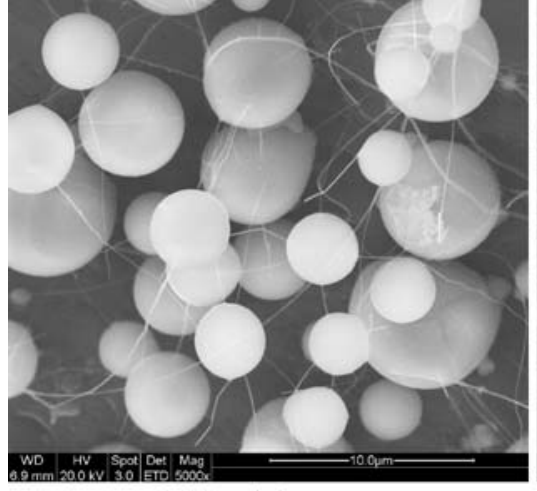

(a)

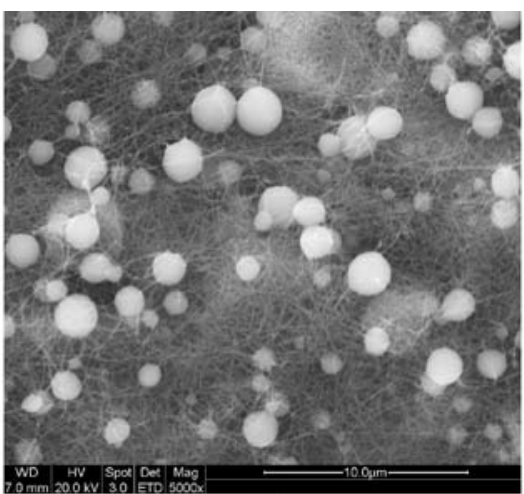

(b)

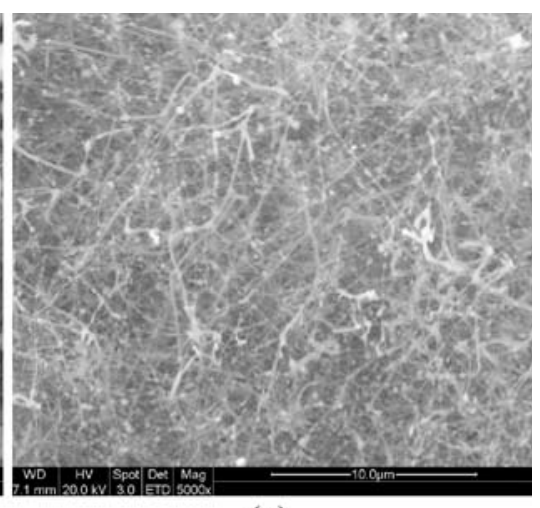

(c)

Fig. 5-Phase change of sample fired at $1400{ }^{\circ} \mathrm{C}$ from the outer part to inner part (magnification 5000 times).

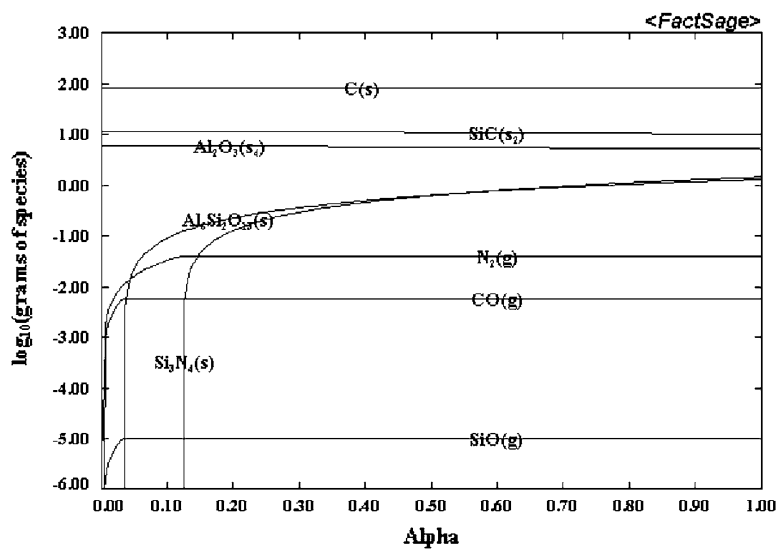

(a) $1100^{\circ} \mathrm{C}$

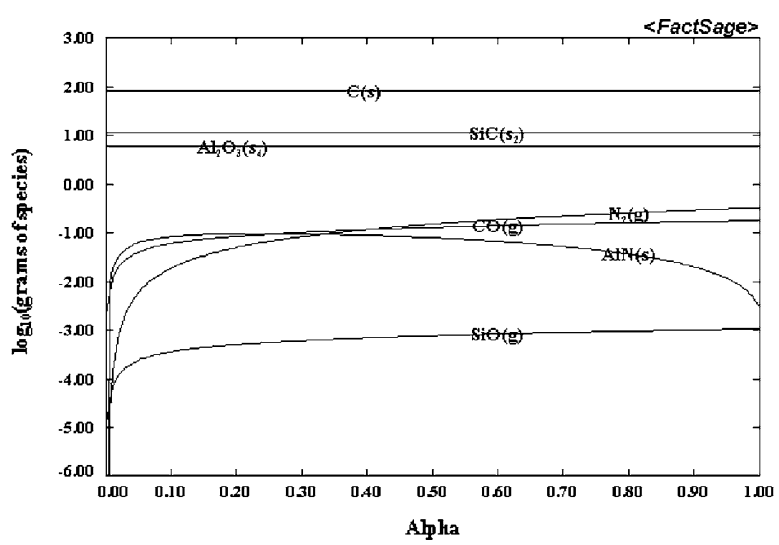

(c) $1400^{\circ} \mathrm{C}$

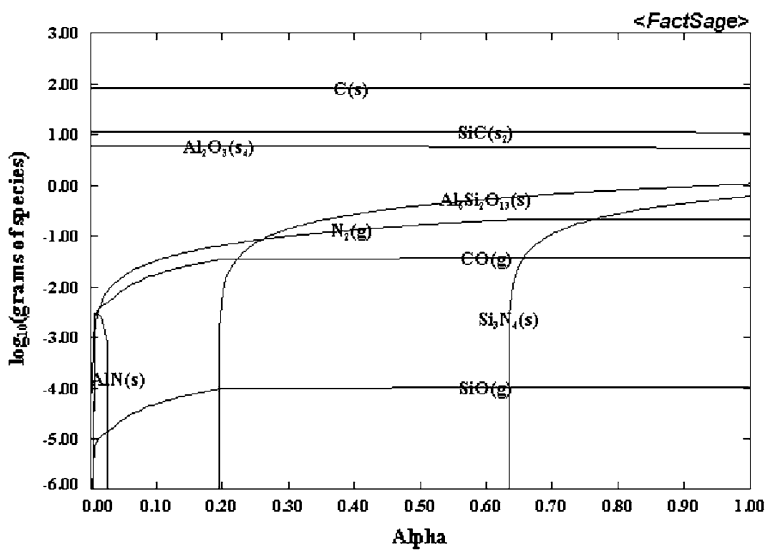

(b) $1200^{\circ} \mathrm{C}$

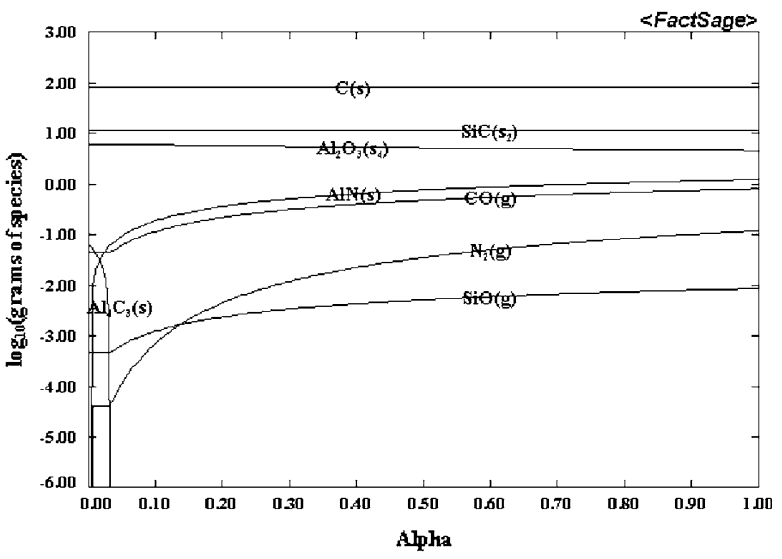

(d) $1600^{\circ} \mathrm{C}$

Fig. 6- Phase changes of specimens fired at the indicated temperatures in coke breeze packing.

calculation process. The calculation was made under the atmosphere of $3.5 \times 10^{4} \mathrm{~Pa} \mathrm{CO}$ and $6.5 \times 10^{4} \mathrm{~Pa}$ $\mathrm{N}_{2},{ }^{[17]}$ and the parameter $\alpha$ was defined as the weight ratio of atmosphere gas to carbon brick sample. At $1100{ }^{\circ} \mathrm{C}, \mathrm{Si}$ is an unstable phase, and when $\alpha$ is close to zero, the amount of $\mathrm{SiC}$ and $\mathrm{Al}_{2} \mathrm{O}_{3}$ is high and decreases slightly with increasing $\alpha$. With an increase in $\alpha$ to $\sim 0.030$, the amount of $\mathrm{Al}_{6} \mathrm{Si}_{2} \mathrm{O}_{13}, \mathrm{CO}$, and $\mathrm{SiO}$ suddenly increases and thereafter $\mathrm{Al}_{6} \mathrm{Si}_{2} \mathrm{O}_{13}$ content continuously increases, whereas the $\mathrm{CO}\left(10^{-2.2} \mathrm{~g}\right)$ and $\mathrm{SiO}\left(10^{-5} \mathrm{~g}\right)$ contents remain constant. When $\alpha$ is $\sim 0.125$, the amount of $\mathrm{N}_{2}$ and $\mathrm{Si}_{3} \mathrm{~N}_{4}$ suddenly increases and the $\mathrm{Si}_{3} \mathrm{~N}_{4}$ content continues increasing, whereas the $\mathrm{N}_{2}$ remains constant with further increase in $\alpha$ (Figure 6(a)). At $1200{ }^{\circ} \mathrm{C}$, AlN disappears suddenly with increasing $\alpha$; the amount of $\mathrm{Al}_{6} \mathrm{Si}_{2} \mathrm{O}_{13}$ and $\mathrm{Si}_{3} \mathrm{~N}_{4}$ increases abruptly when 
$\alpha$ is $\sim 0.20$ and 0.63 , respectively; and the CO $\left(10^{-1.5} \mathrm{~g}\right)$ and $\mathrm{SiO}\left(10^{-4} \mathrm{~g}\right)$ contents are higher compared to those at $1100{ }^{\circ} \mathrm{C}$ (Figure 6(b)). At $1400{ }^{\circ} \mathrm{C}, \mathrm{Al}_{6} \mathrm{Si}_{2} \mathrm{O}_{13}$ and $\mathrm{Si}_{3} \mathrm{~N}_{4}$ no longer exist and the amount of $\mathrm{CO}\left(10^{-2}\right.$ to $\left.10^{-0.8} \mathrm{~g}\right), \mathrm{SiO}\left(10^{-4}\right.$ to $\left.10^{-3} \mathrm{~g}\right)$, and $\mathrm{AlN}$ suddenly increases initially and thereafter $\mathrm{CO}$ and $\mathrm{SiO}$ continuously increase, whereas AlN reduces with $\alpha$ (Figure 6(c)). At $1600{ }^{\circ} \mathrm{C}, \mathrm{Al}_{4} \mathrm{C}_{3}$ occurs and disappears and $\mathrm{Al}_{2} \mathrm{O}_{3}$ decreases slightly as $\alpha$ increases, and the amount of $\mathrm{CO}\left(10^{-1.3}\right.$ to $\left.1 \mathrm{~g}\right), \mathrm{SiO}\left(10^{-3.3}\right.$ to $\left.10^{-2} \mathrm{~g}\right)$, and AlN is higher than it is at lower temperatures (Figure 6(d)).

Thermodynamic calculations indicate that at $1100{ }^{\circ} \mathrm{C}$, when $\mathrm{CO}, \mathrm{N}_{2}$, and $\mathrm{SiO}$ levels are close to zero, $\mathrm{SiC}$, corundum, and $\mathrm{C}$ are the main stable solid phases. In this case, $\mathrm{Si}$ initially reacts with $\mathrm{C}$ to form $\mathrm{SiC}$ :

$$
\mathrm{Si}(\mathrm{s})+\mathrm{C}(\mathrm{s})=\mathrm{SiC}(\mathrm{s})
$$

$\mathrm{Si}_{3} \mathrm{~N}_{4}$ is formed by the reaction of $\mathrm{SiC}$ with $\mathrm{N}_{2}$ from the atmosphere, and the reaction between $\mathrm{SiC}$ and $\mathrm{CO}$ occurs to form $\mathrm{SiO}_{2}$, which further reacts with $\mathrm{Al}_{2} \mathrm{O}_{3}$ to form $\mathrm{Al}_{6} \mathrm{Si}_{2} \mathrm{O}_{13}$ :

$$
\begin{gathered}
3 \mathrm{SiC}(\mathrm{s})+2 \mathrm{~N}_{2}(\mathrm{~g})=\mathrm{Si}_{3} \mathrm{~N}_{4}(\mathrm{~s})+3 \mathrm{C}(\mathrm{s}) \\
\mathrm{SiC}(\mathrm{s})+2 \mathrm{CO}(\mathrm{g})=\mathrm{SiO}_{2}(\mathrm{~s})+3 \mathrm{C}(\mathrm{s}) \\
2 \mathrm{SiO}_{2}(\mathrm{~s})+3 \mathrm{Al}_{2} \mathrm{O}_{3}(\mathrm{~s})=\mathrm{Al}_{6} \mathrm{Si}_{2} \mathrm{O}_{13}(\mathrm{~s})
\end{gathered}
$$

With increasing temperature, the $\mathrm{N}_{2}$ content first increases (maximum at $1200{ }^{\circ} \mathrm{C}$ ) and then decreases. At $1200{ }^{\circ} \mathrm{C}, \mathrm{AlN}$ is formed according to

$$
2 \mathrm{Al}_{2} \mathrm{O}_{3}(\mathrm{~s})+2 \mathrm{~N}_{2}(\mathrm{~g})=4 \mathrm{AlN}(\mathrm{s})+3 \mathrm{O}_{2}(\mathrm{~g})
$$

Up to $1400{ }^{\circ} \mathrm{C}, \mathrm{Al}_{6} \mathrm{Si}_{2} \mathrm{O}_{13}$ and $\mathrm{Si}_{3} \mathrm{~N}_{4}$ disappear according to

$$
\begin{gathered}
\mathrm{Al}_{6} \mathrm{Si}_{2} \mathrm{O}_{13}(\mathrm{~s})=2 \mathrm{SiO}_{2}(\mathrm{~s})+3 \mathrm{Al}_{2} \mathrm{O}_{3}(\mathrm{~s}) \\
\mathrm{Si}_{3} \mathrm{~N}_{4}(\mathrm{~s})+2 \mathrm{CO}(\mathrm{g})=2 \mathrm{SiC}(\mathrm{s})+\mathrm{SiO}_{2}(\mathrm{~s})+2 \mathrm{~N}_{2}(\mathrm{~s})
\end{gathered}
$$

Thereafter, $\mathrm{SiO}_{2}$ formed is reduced by $\mathrm{CO}$ :

$$
\mathrm{SiO}_{2}(\mathrm{~s})+4 \mathrm{CO}(\mathrm{g})=\mathrm{SiC}(\mathrm{s})+3 \mathrm{CO}_{2}(\mathrm{~s})
$$

At $1600{ }^{\circ} \mathrm{C}, \mathrm{Al}_{4} \mathrm{C}_{3}$ is formed by the reaction between $\mathrm{Al}_{2} \mathrm{O}_{3}$ and $\mathrm{CO}$ due to the presence of an increasing amount of $\mathrm{CO}$ :

$$
2 \mathrm{Al}_{2} \mathrm{O}_{3}(\mathrm{~s})+12 \mathrm{CO}(\mathrm{g})=\mathrm{Al}_{4} \mathrm{C}_{3}(\mathrm{~s})+9 \mathrm{CO}_{2}(\mathrm{~g})
$$

The $\mathrm{CO}_{2}$ formed in the system, in turn, is reacted with $\mathrm{C}$ to form $\mathrm{CO}$ :

$$
\mathrm{CO}_{2}(\mathrm{~g})+\mathrm{C}(\mathrm{s})=2 \mathrm{CO}(\mathrm{g})
$$

However, in the fired samples, $\mathrm{SiO}_{2}$ was the only Si-containing compound detected at $1100{ }^{\circ} \mathrm{C}$ (Figure 4(a)), indicating that kinetic factors hindered the formation $\mathrm{SiC}, \mathrm{Si}_{3} \mathrm{~N}_{4}$, and $\mathrm{Al}_{6} \mathrm{Si}_{2} \mathrm{O}_{13}$. At $1200{ }^{\circ} \mathrm{C}, \mathrm{SiO}_{2}$ and $\mathrm{SiC}$ shells were observed on the surface of unreacted $\mathrm{Si}$ (Figure 3(a)), indicating $\mathrm{Si}$ was oxidized by $\mathrm{CO}$. $\mathrm{SiC}$ whiskers were also identified on the unreacted $\mathrm{Si}$ and in the matrix (Figures 3(a) and 4(b)). The presence of large holes in the Si particle was believed to be the result of the direct oxidation of $\mathrm{Si}$ and simultaneous formation and evaporation of $\mathrm{SiO}(\mathrm{g})$ :

$$
\begin{gathered}
\mathrm{Si}(\mathrm{s})+2 \mathrm{CO}(\mathrm{g})=\mathrm{SiO}_{2}(\mathrm{~s})+2 \mathrm{C}(\mathrm{s}) \\
\mathrm{Si}(\mathrm{s})+\mathrm{SiO}_{2}(\mathrm{~s})=2 \mathrm{SiO}(\mathrm{g})
\end{gathered}
$$

$\mathrm{SiC}$ whiskers may be condensed from the vapor phase reaction between $\mathrm{CO}$ and $\mathrm{SiO}$ :

$$
\mathrm{SiO}(\mathrm{g})+3 \mathrm{CO}(\mathrm{g})=\mathrm{SiC}(\mathrm{s})+2 \mathrm{CO}_{2}(\mathrm{~g})
$$

AlN was not found due to the kinetic factor. With increasing temperature to $1400{ }^{\circ} \mathrm{C}$, according to Reaction [8], $\mathrm{SiO}_{2}$ was reduced by $\mathrm{CO}$ and the amount of $\mathrm{SiC}$ formed increased correspondingly. The difference in atmosphere partial pressure from the outer part to inner part of the samples could account for the difference in the phases formed. At $1600{ }^{\circ} \mathrm{C}, \mathrm{Al}_{4} \mathrm{C}_{3}$ did not form due to the kinetic factor.

\section{Property changes}

The weight change of specimens and the percentage of silicon consumed during heat treatment (initial silicon minus the unreacted silicon) are presented in Figure 7. Silicon either reacted to form silicon-containing compounds or vaporized. At firing temperatures below $1400{ }^{\circ} \mathrm{C}$, the weight of the specimens increased, but interestingly it increased only slightly between $1200{ }^{\circ} \mathrm{C}$ and $1400{ }^{\circ} \mathrm{C}$. At temperatures above $1400{ }^{\circ} \mathrm{C}$, it decreased with temperature; the decrease was especially large above $1500{ }^{\circ} \mathrm{C}$. Silicon started to react at temperatures as low as $1100{ }^{\circ} \mathrm{C}$. Approximately $95 \mathrm{wt}$ pct silicon was consumed when the temperature was $1400{ }^{\circ} \mathrm{C}$; thereafter, the silicon consumption changed only slightly. The mass loss observed below $1000{ }^{\circ} \mathrm{C}$ was due to the release of the volatile species of the binder. The increase in mass was a direct consequence of the formation of new silicon-containing phases $\left(\mathrm{SiO}_{2}\right.$ and $\mathrm{SiC})$ during heat treatment, whereas the decrease in mass at temperatures above $1400{ }^{\circ} \mathrm{C}$ was a result of the volatilization of $\mathrm{SiO}(\mathrm{g})$.

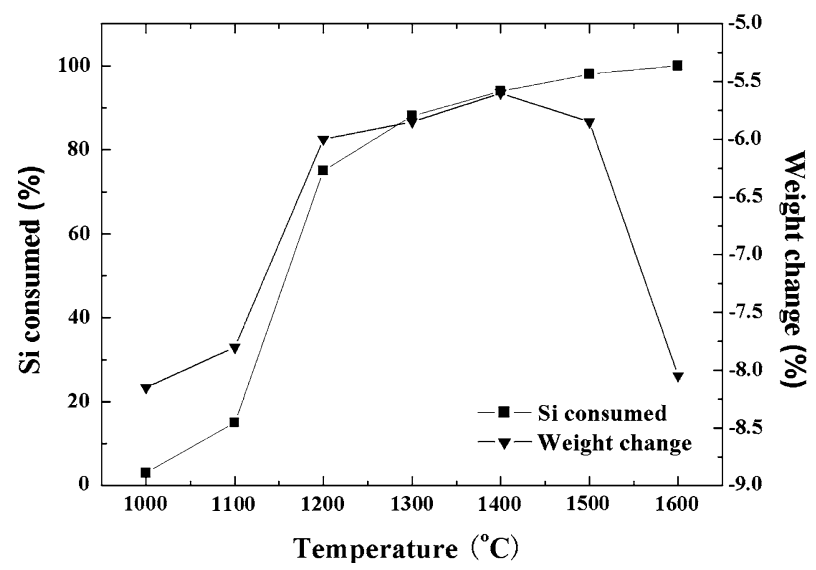

Fig. 7-Weight changes and silicon consumed on heat treatment. 
The evolutions of bulk and true densities of the specimens during heat treatment are illustrated in Figure 8. It is clear that the bulk density of specimens increased with the firing temperature and reached its maximum at $1400{ }^{\circ} \mathrm{C}$, which was $1.65 \mathrm{~g} / \mathrm{cm}^{3}$; it then declined down to $1.58 \mathrm{~g} / \mathrm{cm}^{3}$ at $1600{ }^{\circ} \mathrm{C}$. However, the true density increased slightly with temperature. The trend of bulk density change was similar to that of weight change. The bulk density decrease corresponded well to the apparent porosity increase (Figure 9), which was due to the release of the volatile species and the comparatively large bulk volume change above $1400{ }^{\circ} \mathrm{C}$. The bulk volume change was believed to be due partly to the high anisotropic thermal expansion of the graphite. From $1000{ }^{\circ} \mathrm{C}$ to $1100{ }^{\circ} \mathrm{C}$, the apparent porosity increased and the closed porosity reduced, whereas total porosity changed accordingly, which may be accounted for by the release of the volatile species of the binder. Above $1100{ }^{\circ} \mathrm{C}$, as a general trend, total porosity change was similar to that of apparent porosity, i.e., first declined and then increased, reaching a minimum at $1400{ }^{\circ} \mathrm{C}$, while the closed porosity changed only slightly

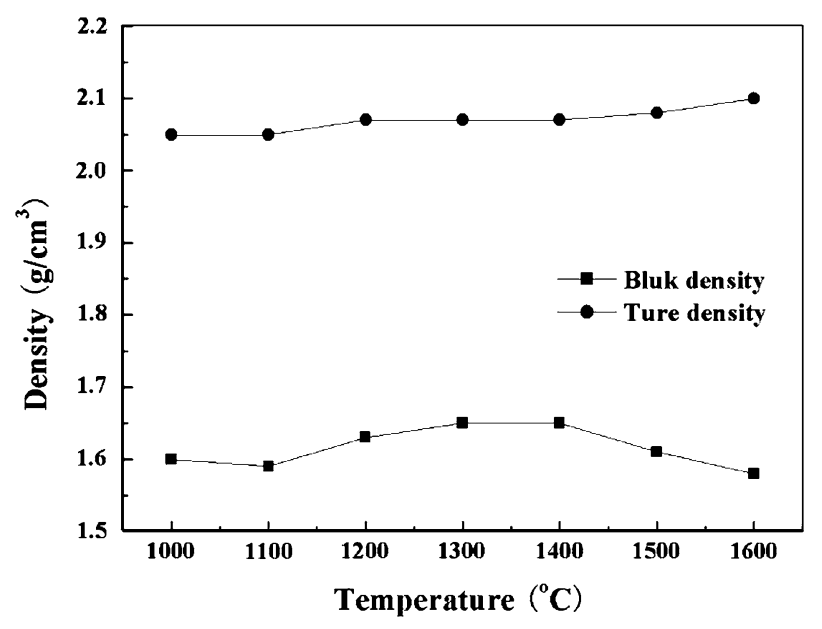

Fig. 8-Bulk density and true density as a function of temperature.

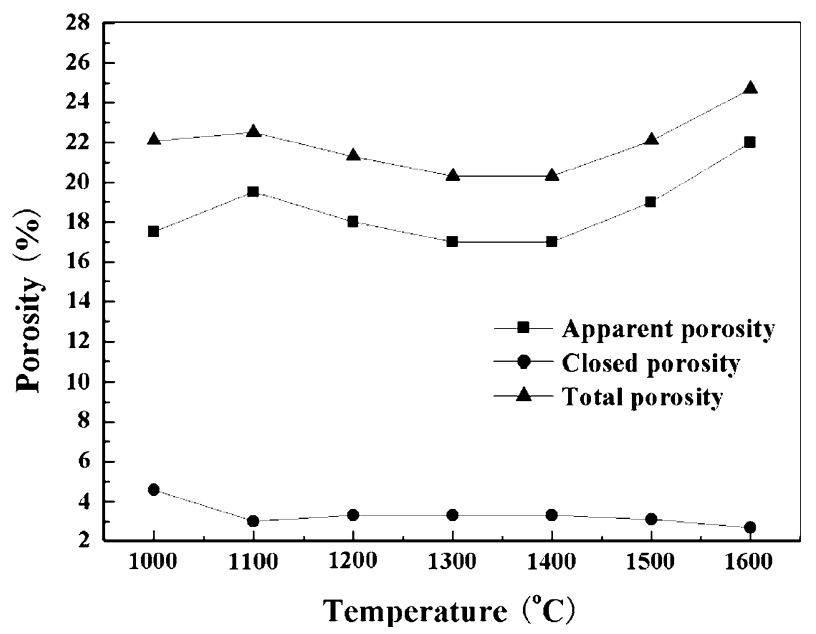

Fig. 9-Porosities as a function of temperature.
(2.8 to $3.0 \mathrm{pct}$ ). The ceramic phases formed in the specimens contributed to the apparent and total porosity decreases, while the volatilization of $\mathrm{SiO}(\mathrm{g})$ resulted in the apparent and total porosity increase.

The micropore size distribution of specimens after firing at different temperatures is shown in Figure 11. The peak corresponding to the pore size diameter $(D) \approx 2 \mu \mathrm{m}$ was observed for the specimen fired at $1000{ }^{\circ} \mathrm{C}$. For the specimens fired at $1200{ }^{\circ} \mathrm{C}$, two peaks appeared: the lower one was at $D \approx 1.8 \mu \mathrm{m}$ and the higher one at $D \approx 0.2 \mu \mathrm{m}$. For the specimens fired at $1400{ }^{\circ} \mathrm{C}$, two peaks at $D \approx 0.17 \mu \mathrm{m}$ and $D \approx 0.25 \mu \mathrm{m}$ were observed, and at $1600^{\circ} \mathrm{C}$, two peaks at $D \approx 0.5 \mu \mathrm{m}$ and $D \approx 0.9 \mu \mathrm{m}$ were detected. In order to better explain the changes in micropore size distribution, the mean diameter and $<1 \mu \mathrm{m}$ micropore volume of open pores at various temperatures were calculated and are presented in Figure 12. It could be seen that the mean diameter of the pores first reduced and then increased as the firing temperature increased from

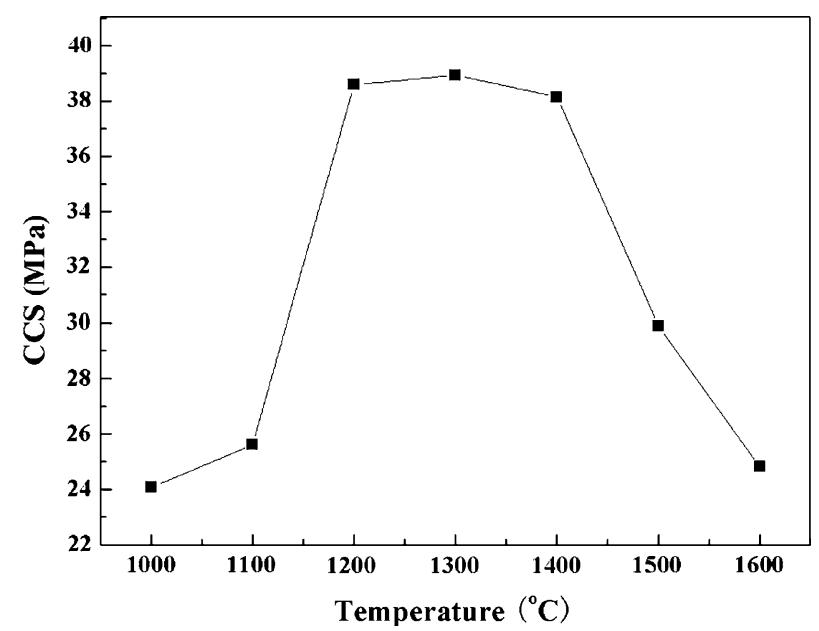

Fig. 10- CCS as a function of temperature.

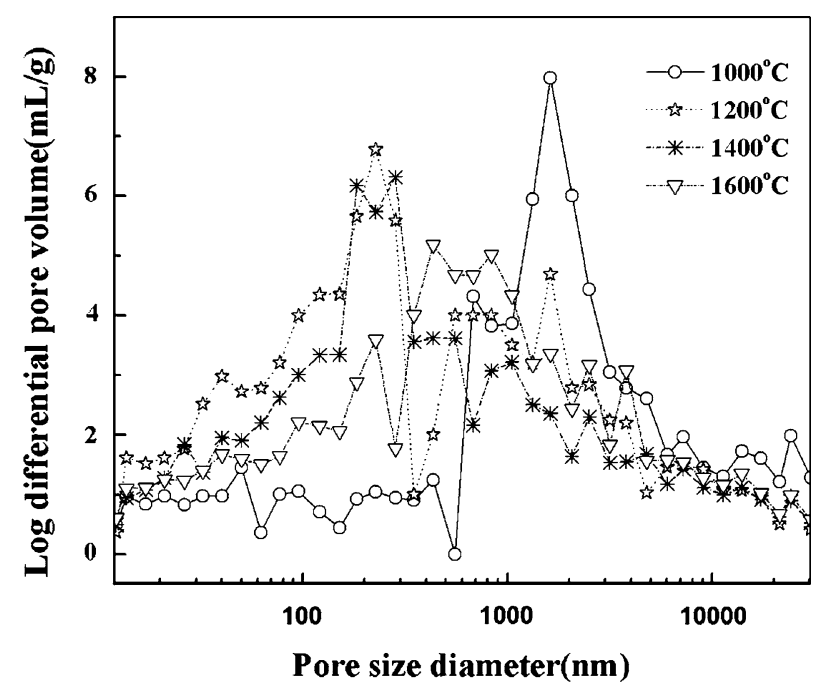

Fig. 11-Micropore size distribution as a function of temperature. 


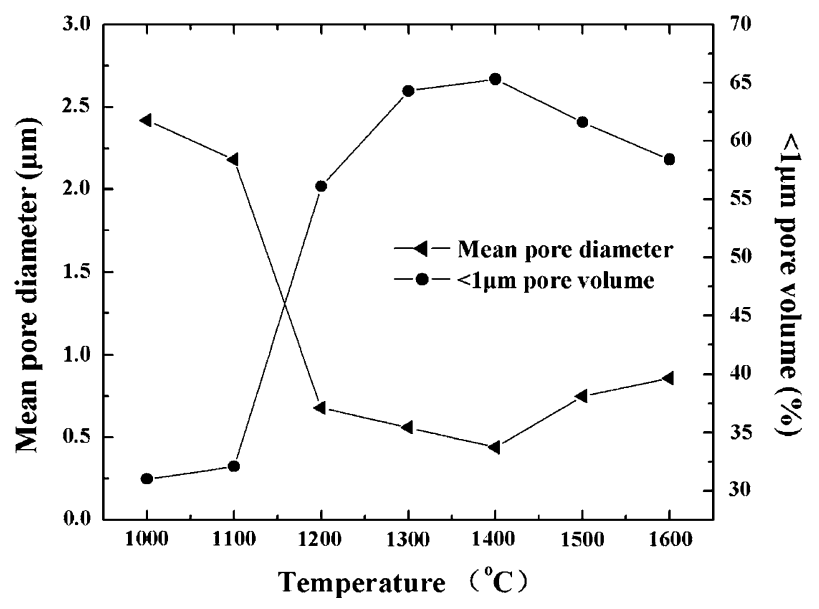

Fig. 12-Mean diameter and $<1-\mu \mathrm{m}$ micropore volume of open pores as a function of temperature.

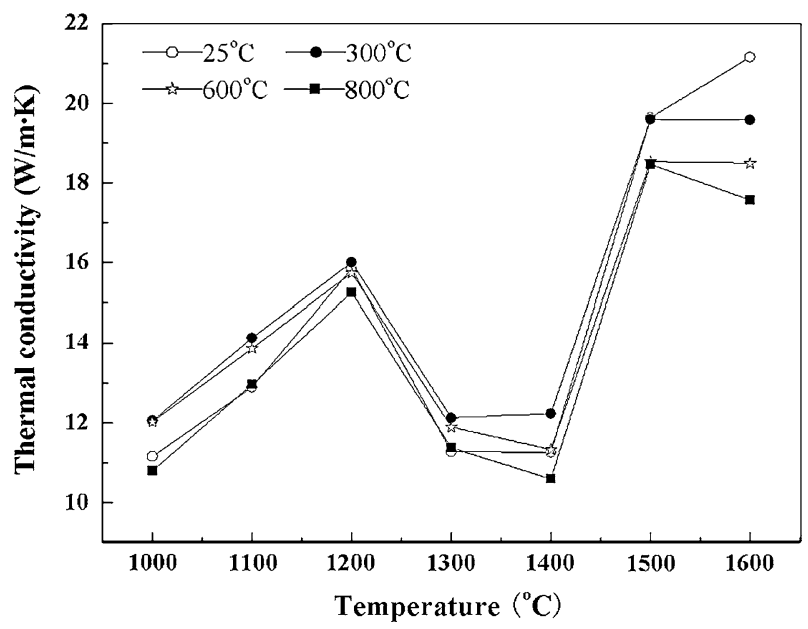

Fig. 13-Thermal conductivity as a function of temperature.

$1000{ }^{\circ} \mathrm{C}$ to $1600{ }^{\circ} \mathrm{C}$; however, the change was not as large as at temperatures below $1200^{\circ} \mathrm{C}$. The $<1 \mu \mathrm{m}$ micropore volume and mean diameter of open pores changed on the opposite directions and reached the respective extremes at $1400{ }^{\circ} \mathrm{C}$.

The CCS of the specimens was measured and the results are given in Figure 10. The maximum strength of $39 \mathrm{MPa}$ was achieved at $1200{ }^{\circ} \mathrm{C}$ to $1400{ }^{\circ} \mathrm{C}$. It should be noted that the trend of the strength mirrored that of the weight change and the bulk density in the range of $1000{ }^{\circ} \mathrm{C}$ to $1600{ }^{\circ} \mathrm{C}$. The results seemed to indicate a strong relationship between the strength and the mass gain on firing.

The thermal conductivity of specimens fired was measured at temperatures of $25^{\circ} \mathrm{C}, 300{ }^{\circ} \mathrm{C}, 600{ }^{\circ} \mathrm{C}$, and $800^{\circ} \mathrm{C}$, and the results are plotted against firing temperature in Figure 13. When the firing temperature was below $1400{ }^{\circ} \mathrm{C}$, the thermal conductivity of specimens first increased and then reduced with a maximum of $15.7 \mathrm{~W} /(\mathrm{m} \cdot \mathrm{K})$ at $600{ }^{\circ} \mathrm{C}$ for the specimens fired at $1200{ }^{\circ} \mathrm{C}$. Thereafter, there was a dramatic increase in thermal conductivity of up to $19 \mathrm{~W} /(\mathrm{m} \cdot \mathrm{K})$ at $600{ }^{\circ} \mathrm{C}$ for

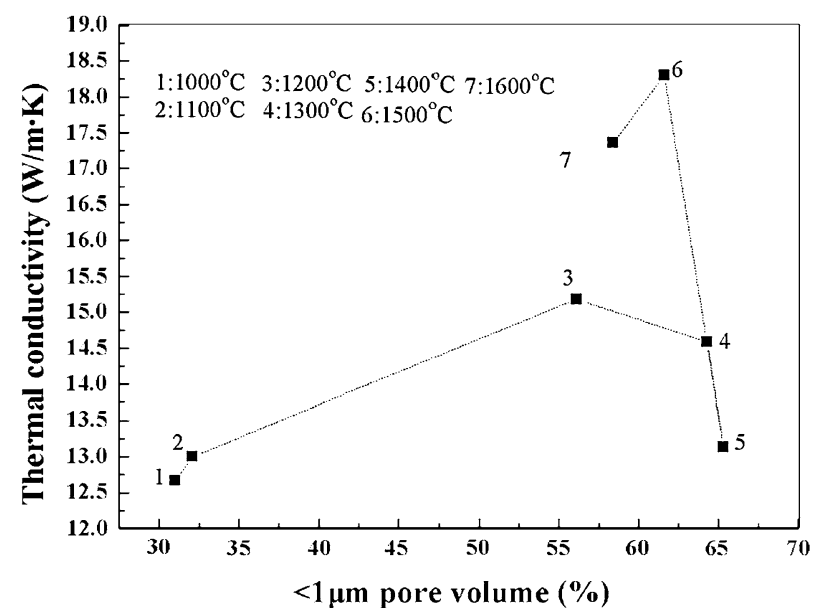

Fig. 14 - Relationship of thermal conductivity at $600^{\circ} \mathrm{C}$ and $<1-\mu \mathrm{m}$ micropore volume of specimens fired at $1100{ }^{\circ} \mathrm{C}$ to $1600{ }^{\circ} \mathrm{C}$.

specimens fired at $1500{ }^{\circ} \mathrm{C}$. The micropore structure was closely related to the thermal conductivity of specimens. Figure 14 indicates the relationship between thermal conductivity at $600{ }^{\circ} \mathrm{C}$ and $<1 \mu \mathrm{m}$ micropore volume for specimens fired at $1100{ }^{\circ} \mathrm{C}$ to $1600{ }^{\circ} \mathrm{C}$. This shows that the $<1 \mu \mathrm{m}$ micropore volume increased while the thermal conductivity first increased and then declined in the temperature range $1000{ }^{\circ} \mathrm{C}$ to $1400{ }^{\circ} \mathrm{C}$, and the thermal conductivity maximum was reached when the $<1 \mu \mathrm{m}$ micropore volume of open pores was $55 \mathrm{pct}$, i.e., at $1200{ }^{\circ} \mathrm{C}$. Above $1400{ }^{\circ} \mathrm{C}$, the $<1 \mu \mathrm{m}$ micropore volume of open pores reduced while the thermal conductivity augmented. In the temperature range of $1200{ }^{\circ} \mathrm{C}$ to $1500{ }^{\circ} \mathrm{C}$, the change of thermal conductivity was in the direction opposite that of the $<1 \mu \mathrm{m}$ micropore volume of open pores. The results seemed to indicate that the thermal conductivity was strongly related to the micropore volume and the phase change on firing. Increasing the micropore volumes could cause a decrease in the thermal conductivity, whereas the high thermal conductivity ceramics such as $\mathrm{SiC}$ could lead to an increase in the thermal conductivity. At $1000{ }^{\circ} \mathrm{C}$ to $1200{ }^{\circ} \mathrm{C}$, the $>1 \mu \mathrm{m}$ micropore volume of open pores was 45 to 70 pct and the heat was conducted by means of convection; thus, the thermal conductivity was enhanced as the temperature increased. At $1200{ }^{\circ} \mathrm{C}$ to $1400{ }^{\circ} \mathrm{C}$, the effect of micropore on thermal conductivity became dominant, and the thermal conductivity declined as the micropore volume increased. Over $1400{ }^{\circ} \mathrm{C}$, both the micropore and phases formed in the specimens worked together; thermal conductivity effectively improved as the micropore decreased (Figure 12), and the high thermal conductivity $\mathrm{SiC}$ phase content increased (Figures 1 and 4).

\section{CONCLUSIONS}

The following conclusions can be made on the basis of the study of the phases, microstructures, and properties of carbon refractories heat treated at $1000{ }^{\circ} \mathrm{C}$ to $1600{ }^{\circ} \mathrm{C}$ in coke breeze packing. 
1. Temperature played a dominant role in the reaction process of Si. At $1100^{\circ} \mathrm{C}$, Si led to the formation of cristobalite balls, and its content declined while $\beta$-SiC content enhanced with increase in temperature. Dumbbell-shaped $\beta$-SiC whiskers appeared at $1200{ }^{\circ} \mathrm{C}$, and dendritic $\mathrm{SiC}$ whiskers formed at $1400{ }^{\circ} \mathrm{C}$; with further increase in temperature to $1600{ }^{\circ} \mathrm{C}$, part of the $\beta$-SiC whiskers straightened and part of them curled. From the outer to inner part of the specimens at or over $1200{ }^{\circ} \mathrm{C}$, the phases correspondingly changed from cristobalite balls to $\mathrm{SiC}$ whiskers.

2. The density and strength were higher and apparent and total porosity were lower at $1400{ }^{\circ} \mathrm{C}$, owing to the phase evolution in the heat-treatment process.

3. The $<1 \mu \mathrm{m}$ micropore volume of open pores was at a maximum while the mean pore size and thermal conductivity were at a minimum at $1400{ }^{\circ} \mathrm{C}$. The formation of ceramic phases could fill in the pores and reduce the pore diameter, which caused the decrease of thermal conductivity; however, the phases formed such as $\mathrm{SiC}$ could effectively improve thermal conductivity.

\section{ACKNOWLEDGMENTS}

We thank the Department of Education of China for the financial support for this research under the program of the New Century Excellent Talents in University (Grant No. NCET-06-0676).

\section{OPEN ACCESS}

This article is distributed under the terms of the Creative Commons Attribution Noncommercial License which permits any noncommercial use, distribution, and reproduction in any medium, provided the original author(s) and source are credited.

\section{REFERENCES}

1. S.N. Silva, F. Vernilli, S.M. Justus, O.R. Marques, A. Mazine, J.B. Baldo, E. Longo, and J.A. Varela: Ironmaking and Steelmaking, 2005, vol. 32, pp. 459-65.

2. S. Tamura, S. Fujihara, and M. Ikeda: Am. Ceram. Soc. Bull., 1986, vol. 65, pp. 1065-72.

3. F. Vernilli, Jr., S.M. Justus, and S.N. Silva: Mater. Corros., 2005, vol. 56, pp. $475-80$.

4. F. Vernilli, Jr., S.M. Justus, and S.N. Silva: ISIJ Int., 2005, vol. 45, pp. 1871-77.

5. S.M. Justus, S.S. Cava, and L.E. Bastos Soledade: Interceram. Refractories Manual, 2003, pp. 60-65.

6. D. Bandyopadhyay, S.D. Singh, and D. Sanyal: Chem. Eng. J., 2003, vol. 94, pp. 79-92.

7. H.W. Gudenau, M. Scheiwe, and R. Sieger: Steel Res., 1993, vol. 64 , pp. 535-41

8. F. Zhao, D. Peng, L. Gao, and Z. Wang: Naihuo Cailiao, 1997, vol. 31, pp. 211-13 (in Chinese).

9. X. Zhan and M. Song: Naihuo Cailiao, 1998, vol. 32, pp. 15-17 (in Chinese).

10. W. Chen, Q. Chen, Z. Li, and Z. Pang: Ironmaking, 2001, vol. 20, pp. 27-29 (in Chinese).

11. G. Zhang, L. Ma, Z. Xiang, and J. Zhang: Carbon Technol., 2003, pp. 43-47 (in Chinese).

12. Y.W. Li, C.G. Aneziris, X.X. Yi, S.L. Jin, and N. Li: Interceram. Refractories Manual, 2005, pp. 20-23.

13. K. Inoue, K. Akamine, I. Sasaka, J. Yoshitomi, and K. Asano: J. Tech. Assoc. Refractories, 2003, vol. 23, pp. 62-65.

14. M.N. Khezrabadi, J. Javadpour, H.R. Rezaie, and R. Naghizadeh: J. Mater. Sci., 2006, vol. 41, pp. 3027-32.

15. S. Zhang, N.J. Marriott, and W.E. Lee: J. Eur. Ceram. Soc., 2001, vol. 21, pp. 1037-47.

16. W. Vieira and B. Rand: Nature of the Bond in Silicon-containing Alumina-carbon Refractory Composites. Part.1. UNITECR '97, Proc. Unified Int. Tech. Conf. on Refractories, 5th Biennial Worldwide Congress, "Refractories - A Worldwide Technology", 4-7 Nov. 1997, New Orleans, 1997, vol. 2, pp. 831-40.

17. X.L. Chen, Y.B. Li, and Y.W. Li: Ceram. Int., 2008, vol. 34, pp. 1253-59. 